\title{
Research on Investment, Financing and Financial Management of Small and Medium-sized Enterprises
}

\author{
Jiafeng Wan \\ Finance and Economics College, Jiangxi University of Technology, Nanchang, 330098, China
}

Keywords: Small and medium-sized enterprises, Investment and financing, Financial management

\begin{abstract}
Small and medium-sized enterprises always have an important status no matter in western developed countries or in numerous developing countries, especially in China. In China, there are abundant small and medium-sized enterprises playing an outstanding role. Stable development of small and medium-sized enterprises is quite beneficial for maintaining the vitality of the present Chinese market. Moreover, small and medium-sized enterprises also created more employment opportunities and technical innovation achievements, capable of realizing coordinated optimization of industrial structure. Therefore, it seems quite urgent for enhancing relevant researches on investment, financing and financial management of small and medium-sized enterprises. This paper states the relationship between investment \& financing and financial management, analyzes prominent problems in investment \& financing and financial management, and proposes several countermeasures for strengthening investment \& financing and financial management in small and medium-sized enterprises.
\end{abstract}

\section{Introduction}

Considering continuous deepening of reform and opening-up in China, it becomes more and more prominent for the status of various small and medium-sized enterprises in China's national economic system. Moreover, small and medium-sized enterprises also got rapid development in China. However, Chinese small and medium-sized enterprises are also confronted with many issues while keeping rapid development. These issues are mainly embodied in investment, financing and financial management of small and medium-sized enterprises. China has a vast territory. The degree of economic development differs in different regions. At the same time, it also differs for the development level of small and medium-sized enterprises in different regions. With continuous development of economy, continuous improvement is also made to the function of small and medium-sized enterprises in different regions. Some enterprises also have the opportunity to become pillar enterprises in local places. Therefore, it is extremely urgent for enhancing investment, financing and financial management in small and medium-sized enterprises.

\section{Relationship between investment \& financing and financial management in small and medium-sized enterprises}

Financial management is always an important part of overall management in enterprises. Implementation of institutional and standard enterprise financial management can make continuous improvement to fund utilization rate of enterprises, so as to provide better assistance to enterprises in improving management efficiency. At the same time, it is also helpful for improving economic operating environment in enterprises. It is incomplete for economic systems in different enterprises. Therefore, it results in not high financial management capacity. At the same time, difficult investment and financing in small and medium-sized enterprises is also an important factor influencing its development. More fund supports can be provided for development of small and medium-sized enterprise by expanding investment and financing approaches and making the most of means in different types.

Enterprise investment \& financing is closely correlated with financial management in enterprises. Both items mutually influence each other, and maintain the relation of interaction. Investment \& financing, as one of important contents for financial management in small and medium-sized 
enterprises, plays a very important role in financial management. Financial management in small and medium-sized enterprises emphasizes investment, financing and fund operation \& distribution. For continuous development of small and medium-sized enterprises, it is of great significance for investment and financing of enterprises in small and medium-sized cities, so as to continuously expand production and operation scale in small and medium-sized enterprises. However, there are still certain risks in the process of investment and financing in small and medium-sized enterprises. Thus, it requires accurate assessment for investment and financing activities and effective reduction to the occurrence rate of investment and financing risks in small and medium-sized enterprises. Thus, fund safety and stability can be guaranteed in small and medium-sized enterprises, so as to further promote better financial management in small and medium-sized enterprises.

Investment \& financing is an important currency approach for development of fund-raising activities for the purpose of guaranteeing funds necessary for enterprise production and operation. Development of direct or indirect investment and financing activities can make continuous improvement to fund strength of small and medium-sized enterprises, and provide stronger fund supports to small and medium-sized enterprises for expanding development scale. At present, principal investment and financing modes of Chinese small and medium-sized enterprises include financial institution investment \& financing, financial fund investment \& financing, commercial investment \& financing, security investment \& financing and international investment \& financing. Application of the said investment and financing modes can help small and medium-sized enterprises to obtain more precious funds, so as to realize reasonable fund utilization in small and medium-sized enterprises.

\section{Prominent problems about investment, financing and financial management facing small and medium-sized enterprises}

Investment \& financing is closely correlated with financial management in enterprises. It is of significant promotion for development of small and medium-sized enterprises. However, there are lots of contents about financial management in small and medium-sized enterprises. At the same time, it may also influence better implementation of financial management in small and medium-sized enterprises. It is incomplete for financial management system in small and medium-sized enterprises, resulting in many issues in enterprise financing. For instance:

Firstly, it is urgent to complete the financial management system in small and medium-sized enterprises. Fund management is a kind of rigorous management behavior. Therefore, small and medium-sized enterprises should adopt standard financial management means, and give full play to the outstanding function of financial management. Various small and medium-sized enterprises already realized great significance of financial management. However, they fail to make complete financial management mechanism. Besides, it is unreasonable for financial management method. They fail to realize the purpose of financial management, resulting in chaos in enterprise financial management and not high utilization rate of fund. This issue is extremely prominent in financial management in Chinese small and medium-sized enterprises. The reason is that many small and medium-sized enterprises were jointly established by one or several investors. Rights in the enterprise usually concentrate on investors. Thus, financial management is of great randomness and changeability, thus influencing improvement to financial management in Chinese small and medium-sized enterprises.

Secondly, it is non-standard for financial management mechanism in the enterprise. At present, lots of financial management systems have been formulated for financial management in small and medium-sized enterprises in China. However, it is not obvious for implementation of these systems in small and medium-sized enterprises. It is mainly caused by the fact that financial management is directly correlated with normal enterprise operation and development. Responsible persons of some enterprises are reluctant to hand over too many rights to financial workers. As a result, the behavior of concentration of power is always found in financial management of small and medium-sized enterprises. More seriously, internal leaders exceed their power to implement financial management, 
seriously influencing institutionalization of financial management in China. It is easy to cause crossed work tasks in financial management.

Thirdly, low financial management capacity results in shortage of financing capacity. Financial accounting can be regarded as an important part of financial management in small and medium-sized enterprises, which will directly affect actual fund conditions in operation of small and medium-sized enterprises. At the same time, it is also closely correlated with enterprise economic benefit. Excessive emphasis on financial accounting causes the tendency of emphasis on business accounting and negligence of management in some small and medium-sized enterprises. In terms of financial management, some small and medium-sized enterprises are reluctant to invest many funds into enterprise production and operation, causing lots of idle funds and thus remarkably affecting the utilization rate of financial fund in small and medium-sized enterprises. The reason is that these small and medium-sized enterprises are still in the initial stage. Their fund conditions are not ideal. It is urgent for improvement to their reputation in the society. However, the state fails to give great policy supports to these new enterprises. As a result, many enterprises are involved in poor investment and financing capacity.

\section{Several countermeasures for strengthening investment, financing and financial management in small and medium-sized enterprises}

\section{Complete credit guarantee system in small and medium-sized enterprises}

Completion of credit guarantee system in small and medium-sized enterprises can effectively reduce information transaction costs between enterprises and financial institutions. Thus, it is helpful for properly settling information dissymmetry between small \& medium-sized enterprises and financial institutions. Therefore, we should devote ourselves to improving the establishment level of credit guarantee system in small and medium-sized enterprises, vigorously promoting the establishment of small and medium-sized enterprises in various regions, and completing the guarantee work system in province, municipality and county (city, or district). Various guarantee institutions should form systems of co-insurance, reinsurance and joint guarantee, and give effective play to overall function of credit guarantee system. In terms of special fund arrangement in small and medium-sized enterprises, we should give corresponding risk compensation. Various regions should combine practical conditions, make great efforts to raise fund, and practically enhance construction of credit guarantee in small and medium-sized enterprises. Commercial banks should radically change ideas, and comprehensively apply talent, fund and information advantages to help various guarantee institutions to complete system and improve risk prevention and control ability. At present, Chinese small and medium-sized enterprises are distinctively featured by flat management, uneasiness to be understood by the outside world, low fund quality, and short-term and urgent fund demand. Therefore, we should reasonably apply guarantee institutions to get familiar with local enterprises and master comprehensive advantages, form complementary advantages with local guarantee institutions, positively explore for new cooperation mode with guarantee institutions, and expand the field and scope of cooperation.

\section{Define property relations of enterprises for implementation of reasonable orientation}

Investment and financing platform enterprises of various local governments should be established by relevant local governmental departments and institutions by the mode of fiscal appropriation or investment in land and stock right. Government, as the only and one shareholder, is entrusted by the board of directors to execute rights and interests of shareholders. However, clear property relation is always misunderstood by people. Viewed from the angle of stockholders' equity appeal, Chinese local governments fail to realize diversity in investment and financing platform enterprises. Their behaviors should comprehensively embody rights and interests of the government as a shareholder. Under the overall background of deepening the reform of service-oriented government, the government's rights and interests are represented in the purpose of public management in most cases. However, investment and financing platform enterprises of various local governments are always 
incorrectly assigned to the nature of microcosmic subject in the market, leading to various conflicts and contradictions between commercial behaviors and public management behaviors of the government in market orientation. Therefore, investment and financing platform enterprises of various local governments should maintain different operation with enterprises featured by diversity of equities, and determine their goals mainly of social benefit and accompanied by economic interest.

\section{Complete enterprise governance structure and improve fund management benefit}

Although investment and financing platform enterprises of local governments should orientate their goals at improvement to social benefit, it is also necessary to make great efforts to realize management of state-owned properties. It can be realized by completing governance structure and reasonably allocating relevant human resources. To complete governance structure of modern enterprises, it is necessary to further define the commission and agency relations between the government and enterprises. The government is served as a shareholder. The board of directors is entrusted to agent relevant rights and interests of shareholders. All members of the board of directors are selected by all shareholders. After the determination, the government needs to change its ideas, and radically break through jurisdiction opinions in traditional sense. The president of an enterprise should implement reform, continuously complete benefit of supervision assets and important right of strategic decision-making, and reduce enforcement of rights. Conversely, continuous improvement needs to be made to management level, project-related business decision-marking rights and executive right. Moreover, enterprises should also produce completely through the mode of market in strict accordance with relevant requirements of professional managers, adopt more effective performance assessment and compensation management systems, further motivate their initiative, apply specialized management advantages in a better way, and make continuous improvement to fund utilization.

\section{Implement restriction mechanism for control of debt risk}

It is necessary for investment and financing platform enterprises of local governments with solely state-owned nature to set single fund account, and join in financial budget system of local government, so as to be under supervision of public fund at any time and further promote standardization of its investment and financing behaviors. At the same time, it is also necessary to positively introduce market constraint modes, and positively participate into credit management and financial business indicator management of local governments' investment and financing platforms by entrusting accountant, layer and other professional rating agencies, so as to reflect actual credit conditions in a more objective and more comprehensive way, and improve information transparency. At the same time, it is also necessary to form financial early warning mechanism of local governments, use for reference mature methods to list debt ratio, debt servicing ratio and others as major indicators, define relevant indicators, determine relevant standards, and positively monitor relevant risks about government financial management. To guarantee debt repayment ability of small and medium-sized enterprises, professional debt repayment funds can be established. On the basis of authentic right, accountability system between responsible departments and workers should be formed by jointly agreeing both parties' investment with financial platforms. Moreover, persons violating relevant disciplines and provisions should be strictly punished, so as to guarantee safety of fund use.

\section{Improve the quality of financial management in small and medium-sized enterprises}

Financial management is of great significance for development of small and medium-sized enterprises in China. We should improve transparency of financial management and enhance the responsibility consciousness of financial management in small and medium-sized enterprises. Such action can guarantee the feature of constraint among small and medium-sized enterprises, and improve safety and rationality of enterprise information management, so as to guarantee sustainable development of small and medium-sized enterprises. At the same time, Chinese small and medium-sized enterprises should also employ professional financial management workers, improve comprehensive quality of these workers, standardize the implementation of financial management, enhance the quality of financial management in Chinese enterprises, and guarantee healthy 
development of small and medium-sized enterprises. Local governments should complete investment and financing platforms, vigorously support sustainable development of national economy and local infrastructure construction. Certain deficiencies exist, and the environment is complicated. However, it is still necessary to seek for positive development, make reasonable orientation, improve the investment and financing structure, and implement the reform of risk management, investment and financing.

\section{Conclusion}

To sum up, relevant governmental departments should give positive assistance, and take various measures to effectively solve financing difficulties in small and medium-sized enterprises, help these enterprises to realize investment and financing to the maximum extent, and promote their enhancement of financial management. Considering this, small and medium-sized enterprises should strictly manage investment, financing and financial management, so as to remain invincible in more and more fierce market competition environment and achieve new development.

\section{References}

[1] Sui Yuming and Wang Xueling, Research on Relevant Issues about Enterprise Financial Management and Enterprise Financing Channel, China Management Informationization, 2010 (13);

[2] Zheng Xinna, Discussion on Issues Existing in Financial Management of Small and Medium-sized Enterprises and Relevant Countermeasures, Financial Accounting Analysis, 2011 (5);

[3] Yi Fajun, Discussion on Issues Existing in Enterprise Financial Management and Relevant Countermeasures, Research of Financial \& Accounting, 2011 (23);

[4] Song Weisha, Discussion on Issues Existing in Enterprise Financial Management and Measures for Enhancing Financial Management, Heilongjiang Science and Technology Information, 2012 (33);

[5] Chen Xin, Discussion on Relevant Issues about Financing Channel of Small and Medium-sized Enterprises, Financial Insurance, 2013 (15) 